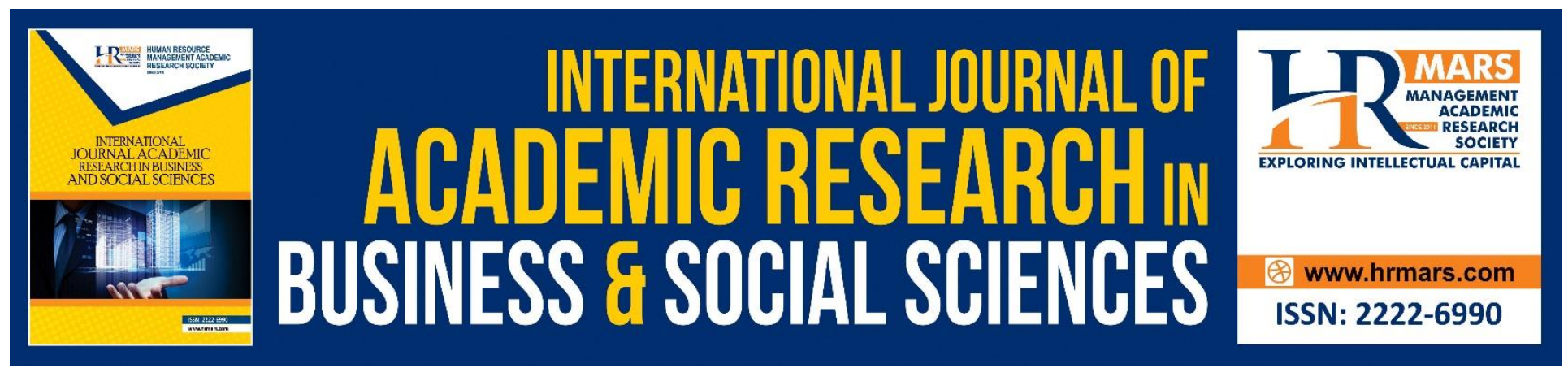

\title{
Relationship Between Youths' Attitudes and Beliefs Towards Violence in Foreign Movies
}

Akmar Hayati Ahmad Ghazali, Kalaivani A/P Munusamy

To Link this Article: http://dx.doi.org/10.6007/IJARBSS/v10-i15/8234 DOI:10.6007/IJARBSS/v10-i15/8234

Received: 21 September 2020, Revised: 19 October 2020, Accepted: 18 November 2020

Published Online: 30 November 2020

In-Text Citation: (Ghazali \& Munusamy, 2020)

To Cite this Article: Ghazali, A. H. A., \& Munusamy, K. A. (2020). Relationship Between Youths' Attitudes and Beliefs Towards Violence in Foreign Movies. International Journal of Academic Research in Business and Social Sciences, 10(15), 67-84.

\section{Copyright: (c) 2020 The Author(s)}

Published by Human Resource Management Academic Research Society (www.hrmars.com)

This article is published under the Creative Commons Attribution (CC BY 4.0) license. Anyone may reproduce, distribute, translate and create derivative works of this article (for both commercial and non-commercial purposes), subject to full attribution to the original publication and authors. The full terms of this license may be seen

at: $\underline{\text { http://creativecommons.org/licences/by/4.0/legalcode }}$

Special Issue: Youth and Community Wellbeing: Issues, Challenges and Opportunities for Empowerment V1, 2020, Pg. 67 - 84

Full Terms \& Conditions of access and use can be found at http://hrmars.com/index.php/pages/detail/publication-ethics 


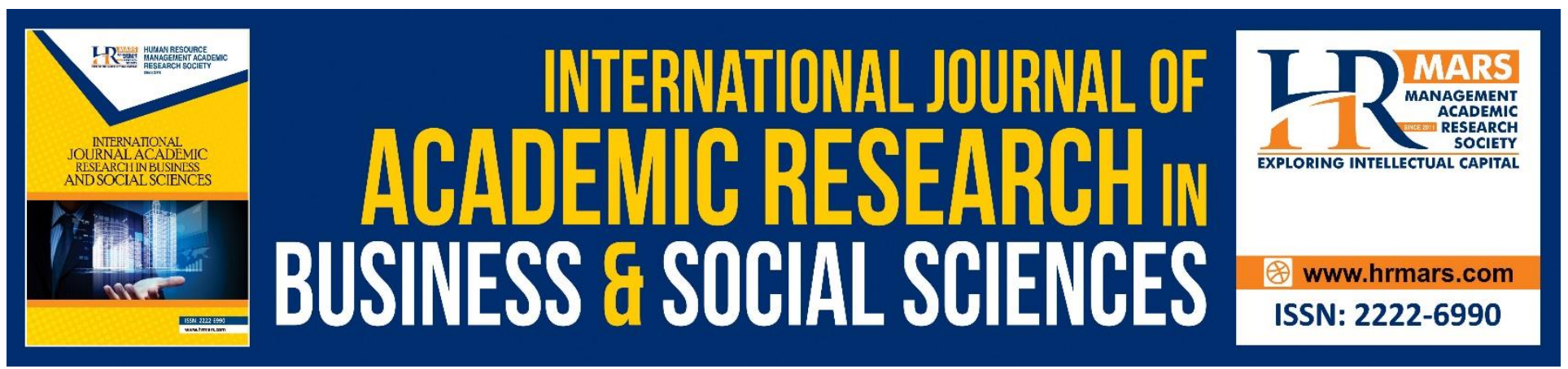

\title{
Relationship Between Youths' Attitudes and Beliefs Towards Violence in Foreign Movies
}

\author{
Akmar Hayati Ahmad Ghazali \\ Institute for Social Science Studies, Universiti Putra Malaysia, 43400 Serdang, Selangor, Malaysia \\ Faculty of Modern Languages and Communication, Universiti Putra Malaysia, 43400 Serdang, \\ Selangor, Malaysia \\ Email: akmar@upm.edu.my
}

Kalaivani A/P Munusamy

Institute for Social Science Studies, Universiti Putra Malaysia, 43400 Serdang, Selangor, Malaysia

Faculty of Modern Languages and Communication, Universiti Putra Malaysia, 43400 Serdang,

Selangor, Malaysia

Email: ani_vani88@yahoo.com

\begin{abstract}
Violence in movie is one of the specific learning conditions believed to be a potential contributor towards the growth of violent behaviour among youths. The purpose of this paper is to examine the relationship between exposure of violent scenes in foreign movies and the violent behavior among Indian youths. A quantitative study involved 400 Indian youths aged between 15 to 19 years old. To select the respondents, a convenient sampling was performed. The data was analyzed using SPSS. The results show that Indian youths who watch Tamil movie more than 4 hours per day would be more influenced with the exposure of violence and it is associated with the increase in violent behaviour. It can be concluded that there is a positive connection between violence in Tamil movie on attitudes, beliefs and violent behaviour. Findings from this study can be used to explore a more effective way such as increasing control from parents to overcome violent behaviour among youths. Film Censorship Board (LPF) has to filter and ban the screening of violent movies. Thus, it could prevent and can help in combating screening of violent actions movies and future research.
\end{abstract}

Keywords: Violence, Youths, Behavior, Attitude, Belief and Foreign Movies

\section{Introduction}

Mass media, which includes print media, electronic media and the internet, have strong influence on the adolescents. It shapes their beliefs, values and behaviors (Rivadneyra, 2006). This is because people started to believe whatever the media shows up is real (Zafar \& Chaudhary, 2018). The media 
provides information about the social, economic, politic and cultural aspects of the human existence. Rahim, Ping, Yin and Phil (2015), assert that violence is a prevalent term in media language and has become an indispensable part of our life. Therefore, screening violent acts in the media especially the television may have harmful effects towards the viewers (Rahim, Ping, Yin \& Pill, 2015). This is mainly because television is one of medium that delivered information to the audience.

Indeed, Uhlmann and Swanson (2004) claimed that it is significantly proven that watching violence movies has huge effects towards violent cognition, on aggressive performance, violent effects, physiological provocations and prosocial behavior. Most of the youth prefer to watch television whereby indirectly they will be affected by the antagonist character in the shows. Therefore, exposure to violence in the media increased the level of desensitization towards violence, increased level of defiance, increase problematic peer and decreased parental relationships (Bushman \& Anderson, 2009; Ostrov, Gentile, \& Crick, 2006; Krahe, 2012).

Most of the movies and programmes screened on the television nowadays are competing to show the hottest and unpredictable scenes to attract the audience. This phenomenon is one of the main causes that spread violent culture to the audience (Gagne, Drapeau, Melancon, Saint-jacques \& Lepine, 2007). According to Yaacop (2010), violence in the media raises juvenile problem among the youth. He continued that some artists who acted in movies tend to be involved in significant deviance culture like black metal and drug abuse.

Browne and Hamilton-Giachritsis (2005), stated that violent scene on the television is a catalyst which increases violent behaviour among the youth. This statement is supported by Subramanian (2007), who mentioned that the global community is aware of and accepts that films have influence and impact on the society. Therefore, media is one of the medium that influences the viewers and impacts on their behaviour.

There are varied strategies of violence present on the television with opportunity to develop an extensive repertoire of aggressive scripts, including scripts for physical aggression, object aggression, and verbal aggression (Rosenkoetter, Rosenkoetter, \& Acock, 2009). Media nowadays tends to highlight more violence which gives negative influence among the juvenile minds (Brains, 2015). Brains (2015), asserted that violent activities are increasing day by day because violent scenes trigger violent behaviour among the children and illiterate Indians.

According to Pendakur (2003), Tamil movies are the most powerful medium of the cultural expression which function's as social, cultural, political and economic institutions. It also has a big impact on the audience life by shaping them into real life. In addition, it is a fantasy world which persuades and influences the audience. Thus, Krishnan (2012) stated Tamil films encouraging and spreading the idea of gangsterism. This is because Tamil cinema has a hypnotic effect towards the masses (Ravi, 2014).

A lot of past studies have examined the exposure to media violence and the increment of aggressive attitude and delinquent behaviors among the youth (Weaver \& Wilson, 2009). In addition, Moon and Lee (2020) asserts past studies revealed films can affect on people beliefs, perceptions and prejudices. This issue should be overcome and solved immediately so that violence in the media does not affect the viewers especially youths. This is because these youths are the future generation to lead the country's development and become future leaders. This problem should be given special attention immediately to control the spreading of negative impact on the audience. 
The electronic media especially the television is one of the medium that can have an impact in terms of influencing the viewers and their behaviour. Yahaya, Lee, Ma'alip and Dunggi (2014), asserted that the television and films highlight the yellow culture that created problems towards the physical behaviour, verbal and nonverbal, aggressive and violent behaviour among the teenagers. They also mentioned that exposure to violent scenes in media would affect the youths' thinking and behaviour. By viewing violent scenes in films would also indirectly induce aggression among viewers (Bettencourt, Talley, Benjamin \& Valentine, 2006). It can be said that youths are easily influenced by watching violent action films and causing them to be involved in crime daringly.

For the past 20 years, exposure to violence in the media has increased and violence is seen virtually in films and TV shows (Haswell, 2011). A lot of violent movies are telecast in television through screenings from other countries such as Hong Kong, Hollywood, Bollywood, Kollywood and so on ("Gengster India," 2010). Some of the movies are screened without any filtration ("Gengster India," 2010). Past research showed that violent behavior among youths and the effect of viewing violence acts in the media has already existed in Malaysia (Samsudin, 2003) and that violence in movies has negative effects towards youths because the behavior stimulates the youth mind to be juvenile delinquent. Youths are easy imitating aggressive and violent behavior shown on the television because of the imbalance between their identity and personality with the television. As violence in the mass media is becoming more common, thus this leads to some undesirable effects, particularly on violent behavior among the young generation. Thus, the objective of this paper is to evaluate the relationship between attitudes and belief of viewing violent scenes in foreign movies among Indian youths.

\section{Literature Review}

\section{Youths and Exposure to Television}

Youths are exposed to all kinds of media that could affect positively and negatively with their lives. They tend to be easily accepting and being influenced by media violence around them. Samsudin (2001), commented that youths are highly exposed to the media at 21.3 to 22 hours per week and are engrossed with the wide range of film characteristics such as violent, sensual, thrilling, anxious, sad, curiosity, suspense, and mysticism and adventurous.

The effects of overexposure to the media will cause youths to be active in replicating violence acts seen on television (Samsudin, 2001). This is in line with Nathanson (2002) studies who proved that television strongly gives an emotion effects on the viewer's such various physical and mental health problems especially children and youths, including violent behaviour, desensitisation to violence, hostility, depression, nightmares, fear, and insomnia. At the same time loneliness, selfesteem, will bring into cyberbullying activities (Ghazali, et al, 2020).

Furthermore, Uhlmann and Swanson (2004) claimed it is significantly proven that being exposed to violence in television, films and computer games has huge effects towards the violent cognition, on aggressive performance, violent effects, physiological provocations and prosocial behaviour based on evidence from Meta analyses, longitudinal research and sectional studies.

Antisocial behaviour among adolescents is predicted to bring detrimental impacts to the sustenance of future generation in leading the country development. Overall, media violence seems to cause short-term and long-term effects especially among the viewers who are more engaged with 
the media. Hence, over exposure of violence in television will lead to social problem among the youth. In addition, the developments in mass media such as television and the way people gain knowledge about digital computers changed perception of teenagers about how violent the planet is (Muhammad, 2019).

More than two decades of research have shown that violence portrayed in the media has greatly influenced the attitudes and behaviour of the audience, particularly children (Hassan, et al 2009). Apart from that, there are continuous researches conducted to examine the influence of aggression and violence in the media specifically from television and movies on the children and youths.

According to Jesudoss (2009), the needs of the community are constantly changing and they are not fully satisfied. Therefore, extra elements are infused in the movies like a track of music, dance, lyrics, sex and violent scenes for its products to be well received among the audience (Jesudoss, 2009). Bhrugubanda (2011), pointed out that the main target audience for most Indian publishers are youths who expect good music and interesting story lines to grab the interest of the youth. On the other hand, Govindam (2001) stated that Tamil movies emphasis more on the social life that explains the many varied parts and aspects of everyday life.

Therefore, Tamil film producer Pahlaj Nihalani said producers nowadays give more priority in producing films to satisfy the youth as "young people are the biggest market for them" (Jesudoss, 2009). Thus, it can be said that the movies focus on the audience that consists of youngsters and the moves are also to fulfil their needs and neglected to apply moral values and good examples in their movies. For example, if the viewers enjoy watching movies containing violent elements, the movies released will contain violent elements for the pleasure of the audience.

\section{Attitudes towards Viewing Violence in Movies}

Attitudes towards violence involve hostile feelings that are translated into violent behaviour (Ikeda, Simon, \& Swahn, 2001). Similarly, Duru, Redzuan, Hamsan and Shahrimin (2015), asserted that attitudes towards aggressive behaviour can lead people to engage with violent behaviour. Attitude is determined by various consequences, firstly belief about the aggressive behaviour, secondly the consequences of the sense towards social situations and thirdly those who hold a positive view towards violent acts will be highly committing aggressive behaviour (Vernberg, Jacobs \& Hershberger, 1999). Boulton, Bucci, and Hawker (1999) also stated that a positive view on aggressive acts would develop a positive attitude towards violent behaviour.

According to Velicer, Huckel, and Hansen (2003), there is a significant mediating role between attitudes towards violence and the aggressive feelings which can turn into violent behaviour. Attitudes are believed to guide a person's information process. According to Bushmen and Huesmann (2001), violence in the media will increase aggressive feelings among the viewers by showing them how to aggress, by priming aggressive cognitions including the aggressive scripts used in the media and aggressive perceptual schemata, by increasing arousal, or by creating a state of aggression that may affect others.

A person's behaviour can be predicted by using the strength and consistency of his or her attitude. Attitudes as described by psychologist are formed through experiences in lifetime and are usually determined by beliefs and the evaluation of such beliefs. Many beliefs and values may underpin an attitude (Willock et al., 1999). Attitude simply refers to a person's evaluation of any 
psychological object. Therefore, attitude towards violence plays an important role towards the violent behaviours.

In this case, any intention that is planned of changing the behaviour of an individual must have enough information about her or his attitude. Then only can apply and implement methods that can help them to change.

\section{Beliefs towards Violence by Viewing Violence}

Nowadays, the media becomes the most powerful socialising agent for young children (Linder \& Werner, 2012) and plays a vital role in their life (Coyne, Archer, \& Eslea, 2006). Violence in the media increases aggression (Anderson, 1997). According to Gentile, Coyne, and Walsh (2011), violent exposure in the media can lead to negative effects on the youth. Exposures to violence in the media are positively correlated with aggressive beliefs and behaviours (Gentile, Coyne, \& Walsh, 2011). Hence those who like to watch violent scenes in films may end up believing that the use of violent against others is the best way to spread popularity and power. Therefore, those violent scenes in films are positively correlated with the aggressive beliefs and behaviours after viewing violent acts in the media.

Richmond and Wilson (2008), described that if individuals are repeatedly exposed to violence in the media, it would develop inaccurate beliefs about what they are viewing. Through these inaccurate beliefs, people's moral values will be disengaged, which restructure their views on moral values which make way for violent behaviour (Richmond \& Wilson, 2008). With that, this process will disengage from moral controls and increase the acceptable of violence into their behaviour.

It is believed that attitudes guide a person into the social information process. Beliefs towards violence could inspire and lead a person to behave aggressively or anticipate positive feedback towards violent behaviours (Dodge, 1993). Besides that, it is believed that the influence of aggression significantly initiated the aggressive and violent behaviour. Thus, Bushman (1995) also stated that aggression prone individuals with aggressive behaviour increases after viewing violent movies. Furthermore, according to Savage (2004), beliefs towards watching violent acts in the television or movies cause violent behaviour. Thus, people will adapt the aggressiveness viewed to change their behaviours. According to Chamberland, Fortin, and Laporte (2007), social discourse describes the contrasting belief that people hold between demonstrating self-restraint and seeing aggressions as natural.

In addition, based on some of the experts, observing violence in the media has significantly increased the viewers' beliefs on violence (Berkowitz, 1993). Moreover, Bushman and Geen (1990) stated that viewing violence in the media can increase the aggressive thoughts of the viewers. Those statements revealed that violence screened in the media can effect on the viewers' beliefs towards violence. In other words, violent media increases aggressive thoughts which then spread towards the activation processes. This influences the viewer's beliefs towards violence as shown in the television. Positive beliefs towards violence on the other hand will indicate violence behaviour among the viewers. 


\section{Methods}

\section{Design}

This study used the quantitative method which included questionnaires for data collection. The use of this method has also allowed the questionnaires to be collected in a short time and if there are any doubts on the questionnaire, it can be briefed immediately (Sekaran, 2000). The survey method helps to describe and streamline the questions as well as to help the process of data collection, data analysis and also in answering the research questions accurately and systematically.

\section{Participants}

For this study the population is Indian youths from the age group of 15 - 19 years old from Selangor. The total Indian population in Selangor is 679,130 people and 133,767 of them are in the age group of 15-24 years old (DOSM, 2010). To determine the actual size of the respondents for the survey, the sampling size was taken through the Krejcie and Morgan's table formula, (1970). The researcher had distributed 400 questionnaires to the respondents.

\section{Measures}

The measured variables for this study included the Indian youths viewing habits, attitudes towards viewing violent scenes in Tamil films, beliefs toward violence in Tamil movies and aggressive behavior after viewing violence scenes in Tamil movies.

\section{Demographics}

This consists of four questions related with the respondents of the study. It involves the distribution of gender and age. During the pilot test, the study had open-ended questions and based on the answers, the researched customised the close-ended questions. The types of data classification are according to the dimensions identified, such as the nominal data used to refer the gender and age. As described each value given in a label and arranged in order. For gender there were categorized as code 1 for description male and code 2 refers to female. Moreover, age group also arranged in order as 15 years old, 16 years old, 17 years old, 18 years old and 19 years old. In this section, the questions are designed to represent the variables that have been identified. Respondents are required to tick $(\mathrm{V})$ the appropriate answer for every item.

\section{Television viewing habit}

For media viewing habits there are total of four questions were employed in the form of close ended questions. For examples: duration of watching movie (hours/day; times/week) was asked to the respondents. Secondly, for the days that watched film on television given options such as Monday, Tuesday, Wednesday, Thursday, Friday, Saturday and Sunday followed with time watch movie. Furthermore, respondents also were asked favourite genre movie and genre of television movie being telecast. Therefore, the respondents need to tick $(V)$ the appropriate answer for every item. Attitudes towards violence in Tamil movies

This measures the attitudes concerning aggression toward violence and also has past research questions. For statements related to interests, behaviour and changes on attitude, participants will need to rate each of the 10-statement based on Likert scale 5-point scale ranging from 1 (strongly disagree), 2 (disagree), 3 (somewhat agree), 4 (agree) and 5 (strongly agree). For this section, the respondents need to circle the appropriate number for each statement.

\section{Beliefs towards violence by viewing violence in Tamil movies}


This consists of questions regarding the beliefs towards violence and past questionnaire from previous study are used. Statements regarding interests, feelings and beliefs in the 12 items required the respondents to select their answers based on a 5-point of Likert Scale as in strongly disagree (1), disagree (2), somewhat agree (3), agree (4) and strongly agree (5). For this section, the respondents need to circle the appropriate number for each statement.

\section{Violent behavior}

The Aggressive Questionnaire (Buss \& Perry, 1992) was employed to measure the violent behavior. By using the Aggressive Questionnaire, respondents will answer based on four types of scale namely the physical aggression ( 9 statements), verbal aggression ( 5 statements), anger ( 7 statements) and hostility (8 statements). In this study, respondents will rate each of the statement based on a 5-point of Likert scale ranging from 1 (never true), 2 (rarely true), 3 (sometimes true), 4 (usually true) and 5 (always true).

\section{Data Analysis}

In this study, the descriptive analysis was used to describe the basic data. Descriptive analysis helps to calculate the central tendency such as the mean, median and mode, while measures standard deviation (or variance). It is also concerned with the manners of collecting and organising the data. The data pertaining to the first variable were analysed using the descriptive statistical such as the frequency distribution (percentage), mean and standard deviation. For the first objective, which is to identify and find out the pattern of watching movies on television among Indian youths, the descriptive statistic was employed as well. The correlation analysis was used to attend the objective of this study as well as to examine the relationship between attitudes and beliefs of viewing violence in Tamil movies among Indian youths. The 'correlation coefficient' was coined by Karl Pearson in 1896. The Pearson product-moment correlation coefficient $(r)$ assesses the degree that quantitative variables are linearly related in a sample (Benesty, Chen, Huang, \& Cohen, 2009). In other words, it is used to test the linear relationship between two quantitative variables. Each individual or case must have scores on two quantitative variables while the continuous variables are measured on the interval or ratio scales. The significance test for $r$ evaluates whether there is a linear relationship between the two variables in the population.

\section{Results}

\section{Descriptive Statistics}

There were 400 respondents who took part in this study and the result of respondent's sociodemographic profiles is shown in Table 1 . The result revealed that majority of respondents were female $(55 \%)$ and the remaining were male (45\%). The result indicates that most of the respondents involved are 18 years old youths (27.8\%) and $85 \%$ of the respondents are more than 16 years old. Thus, Muhammud (2012) asserted youths aged 16 years old and above are more abstract and think critically to make decisions. Therefore, this group of youths are more mature and can start making wise decisions. 
Table 1: Socio-Demographic Profiles of Respondents $(n=400)$

\begin{tabular}{lcc}
\hline \hline Profile & Frequency & Percentage (\%) \\
\hline Gender & & 55 \\
$\quad$ Female & 220 & 45 \\
$\quad$ Male & 180 & \\
Age & & 17 \\
15 years old & 68 & 17.5 \\
16 years old & 70 & 22.5 \\
17 years old & 90 & 27.8 \\
18 years old & 111 & 15.3 \\
19 years old & 61 & \\
\hline \hline
\end{tabular}

\section{Television Viewing Habits}

The data in Table 2 presented nearly more than half the youths (55.5\%) watched Tamil movies on television more than 13 times in a week. Indeed, the result of study revealed only 2.3 percent of respondent spent less than one hour to watch television. Thus, watching television is one of the most popular activities among youths (Arnett, 2007). It showed that most of the respondents prefer to spend their time to watch Tamil films in television and exposed to violent scenes in television. This study is in line with Gentile (2014), that greater amount of viewing violence in television and movies tend to engage with higher level of violent behaviour which supports the study.

Table 2: Distribution of Respondents' Television Viewing Habits $(n=400)$

\begin{tabular}{lcc}
\hline \hline & Frequency & Percentage (\%) \\
\hline Watching Tamil movies on television in a week & & \\
$<3$ times & 10 & 2.5 \\
$4-8$ times & 75 & 18.8 \\
$9-13$ times & 93 & 23.3 \\
$>13$ times & 222 & 55.5 \\
Duration of watching Tamil movies per day & & \\
$<1$ hour & 9 & 2.3 \\
1 hour to 2 hour & 26 & 6.5 \\
2 hour to 3 hour & 108 & 27 \\
$>3$ hour & 257 & 64.2 \\
$*$ Day watch movie in television & & \\
Monday & 146 & 36.5 \\
Tuesday & 138 & 34.5 \\
Wednesday & 153 & 38.3 \\
Thursday & 148 & 37 \\
Friday & 208 & 52 \\
Saturday & 313 & 78.3 \\
Sunday & 328 & 82
\end{tabular}




\section{* Favorite Genre movie}

Family

Love

Violence

Spiritual

Sex

Religion

Others
313

230

150

150

41

107

67

332

276

176

133

49

129

41
78.3

57.5

37.5

37.5

10.3

26.8

16.8

80.5

69

44

33.3

12.3

32.3

10.3

* Respondent may provide more than one answer

Moreover, $82 \%$ of the respondent stated that they regularly watched movie in television on Sunday. Other than that, the result revealed that most of the respondents usually watched movie at night (75.3\%) (Table 2). The result indicated that majority of the respondents watched television on Sunday and usually watched television at night. This is because most of the respondents had leisure time on weekends and they prefer to watch television on Sunday.

The respondents were also asked about distribution of genre movie liked watch, genre of movie television telecast and selected channel to watch films. For these category respondents may give more than one response. Genre of the movie is the most important factor that will probably be considered when selecting to watch a specific movie (Desai \& Basuroy, 2005). Based on Table 2, result of the study revealed that more than half of the respondents liked to watch family genre movies (78.3\%).

In addition, majority of respondents (80.5\%) stated genre of movie that television telecast is family genre. For instance, a movie that contains uniqueness such as family value and bonding among family members enhances their interests to watch those movies rather than other genre movies.

Relationship between attitudes and belief of viewing violence in Tamil movies and youths' behavior The result revealed there have a positive and strong correlation between attitudes towards violent behaviour on viewing violence in Tamil movies and the behaviour of Indian youths $(r=0.832 ; p=$ 0.000). The results of the study revealed that higher positive attitudes towards violence could lead the people to engage in violent behaviour. In previous study, it was found that attitudes have a significant relationship towards violent behaviour. In addition, Velicer, Huckel, and Hansen (2003) also asserted that there was a significant mediating role between attitudes towards violence viewed and violent thoughts which can result in violent behaviour. Thus, after viewing violent scenes in movies, youths are more likely to be hostile such as punching or hitting, which affect an individual's 
violent response. Other than that, when they were exposed to violence in media, they became more engaged to committing violence.

This finding supported to the finding of Duru, Redzuan, Hamsan and Shahrimin (2015), which stated that attitude towards violence will lead people to involve themselves in violent behaviour. Thus, positive attitudes towards violence that was viewed in Tamil movies highly affect viewers' behaviour.

Result in Table 3 also showed correlation test between beliefs towards violence in Tamil movies and violent behaviour among the viewers. The correlation between beliefs and violent behaviour by viewing violence in Tamil movies toward the behaviour of Indian youths also showed positive and very strong relationship $(r=0.908 ; p=0.000)$.

Table 3: Relationship between Attitudes and Beliefs towards violent behaviour $(n=400)$

\begin{tabular}{lcc}
\hline \hline Variables & \multicolumn{2}{c}{ Violent Behaviour } \\
\cline { 2 - 3 } & $\mathbf{R}$ & $\mathbf{P}$ \\
\hline Attitudes & 0.832 & $0.000^{* * *}$ \\
Beliefs & 0.908 & $0.000^{* * *}$ \\
\end{tabular}

$* * *$ Correlation is significant at the 0.01 level (1-tailed).

Past research has been shown that youths' beliefs might be affected by exposure of violence in media (Linder \& Werner, 2012). Results of this study also indicated that if Indian youths' belief toward violence that showed in Tamil movies, they would be influenced and start to imitate those actions in their daily life. When youths like to watch violent scenes in movies, they tend to belief and been start implementing violence as the best way to spread popularity and power. Then they started to belief and adapt the violence that was viewed to change their behaviour. Moreover, when they start believe the violence in movies, it will increase aggressive thought among them and spread towards the activation process.

The study also yielded similar findings with Gentile, Coyne, and Walsh (2011), whereby they stated that exposures of violence in media were positively correlated with violent beliefs and behaviours. Therefore, it is strongly proved that those violent scenes viewed in movies would correlate with violent beliefs and behaviours after viewing violence in television.

Therefore, the strength of the relationship between beliefs and violent behaviour should be explored in more depth to determine the strength of the relationship. Hence, to explain the objective of the study which was to identify the relationship between attitudes and beliefs towards violence of viewing violence in Tamil movies and Indian youths' behaviour, researcher developed hypothesis and tested using the Pearson product-moment correlation coefficient.

Correlation analysis assesses the degree that quantitative variables are linearly related in a sample. It is used to test the linear relationship between two quantitative variables. If the $r$ value, more than 0.7 , which indicated the variables had very strong positive correlation, it is acceptable for social science studies (Chin, 1998; Keating \& Matyas 1998; Rankin \& Stokes, 1998). Table 3 summarized the correlation between attitudes and beliefs. The significant correlation between total scores suggested that respondents were influenced by viewing violence in Tamil movies and it affects 
their behaviour. The result showed that there was positive significant relationship between attitudes and beliefs of Indian youths. It is in line with cultivation theory that heavy exposure to television violence stimulate to the aggressive thoughts to violent behaviour.

\section{Discussion}

In this study, the relationship between viewing violence in Tamil movies on television towards Indian youths' behaviour was measured based on attitudes and beliefs. Respondent's media viewing habits affects their behaviour. Based on this study, data revealed that most of the respondents watch television more than 3 hours. As discussed in cultivation theory, heavy viewers who watch movies more than 4 hours per day would be more influenced with the exposure of violence in Tamil movies and it is associated with increase in violent behaviour. Moreover, although they like to watch family genre movies, they also contain violent scenes which will affect the viewers' behaviour.

Majority of the respondents in this study were female and 18 years old. Youths who involved in this study spent a considerable amount of time to watch television and specifically watch Tamil movies on television in a week more than 13 times. Thus, almost more than half of the respondents spent more than three hours to watch Tamil movies in a day and like to watch movies on television on Sunday. Moreover, youths spent their leisure time at night to watch movies.

Finding from this study indicates a positive connection between violence in Tamil movies on attitudes; beliefs and violent behaviour. Overall, it is identified that there is positive association between violence in Tamil moves and violent behaviour. In addition, past research also revealed that there was a strong relationship between violence telecasted in television towards violent behaviour. As reported by researches in cultivation theory, repeated exposure of violence in television widely leads to the acceptance of aggressive changes on attitudes and behaviour. As discussed in Bandura's social learning theory, exposure of media violence contributes to the future aggressive behaviour (Anderson \& Carnagey, 2004).

The result from correlation analysis revealed that attitudes, beliefs were positively correlated. The strongest correlation was found between attitude and violent behaviour on viewing violence in Tamil movies with score $(r=0.832 ; p=0.000)$ and beliefs and violent behaviour on viewing violence in Tamil movies with score $(r=0.908 ; p=0.000)$. The relationship among attitudes, beliefs towards violence in Tamil movies was strong and very significant.

The critics worried that violence telecasted on television such as negative scenes seems acceptable in real life situations. Television is one of the tools that have impact towards youths and long-time exposure to the movies will affect the youth's behaviour. In addition, cultivation-based research supports that it is highly risky to the attitudes and behaviours of the viewers if they are repeatedly exposed of television on violence.

Apart from that, TV programmes and movies are also sources for youths to learn negative behaviour patterns and values (Hassan, Osman \& Azarian, 2009). Increasing control from parents helps in reducing media violence (Hassan et al. 2009). The impacts of this on children can be reduced by proper parental guidance.

Besides that, youths who watch television will imitate the behaviour showed in movies. If the programs or films telecasted on television are not conducive, it will cause youths to not have a good behaviour. Therefore, it is very important for film censorship board to filter out violent scenes in 
Tamil movies before telecasting in television. This is because limited awareness on the violent messages causes it to steadily strengthen in a young viewer's mind and moral values defy in their development. Based on these studies, hopefully data on television violence and its effects towards youths will constitute a clearer understanding for future studies.

However, this study is not without some limitations. There are various limitations in this study. Mainly, there were not many respondents willing to participate in this study. Other than that, in every study, time is always constraint. This study was carried out in Selangor only and it could better if the study gets more samples from other states to represent the entire Indian youths view towards violence in Tamil movies on television. However, a higher cost will be required to extend the research to cover a wider scope.

\section{Conclusion}

Today generations are accustomed to watching television and television violence as part of their daily life. Viewing violence as entertainment will lead towards the effects on aggressive attitudes, beliefs on violence which indicate to the violent behaviour. What is seen in television is believed as reality and it is considered as entertainment for the audience. Cultivation based research also indicates that repeated exposure of violence in television leads towards the acceptance of violence on the attitude and behaviour of the audience. This model showed aggressive behaviour form based on social learning processes. For instance, an individual's action is influenced and affected by internal state represented by affect, cognition, and arousal.

The result of this study, has several implications. Main improvement is needed in the government policy of Film Censorship Board (LPF). Results of this study has clearly shown the positive relationship between violence that watched in Tamil movies towards youth's behaviour. Although there are Acts such as the Broadcasting Act 1988 and the Film Censorship Board (LPF) established in an effort to censor and filter and screening violent action movies, violent acts are still allowed to be screened. Film Censorship Board (LPF) has to filter and ban the screening of violent movies. Thus, it could prevent and can help in combating screening of violent actions movies. The discussions can provide a clear view to youth that violence that showed in movies is different from real life violence its consequences negative impacts to the victims.

\section{Declaration of Conflicting Interests}

The author(s) declared no potential conflicts of interest with respect to the research, authorship, and/or publication of this article.

\section{Funding}

The author(s) received no financial support for the research, authorship, and/or publication of this article

\section{References}

Anderson, C. A. (1997). Effects of violent movies and trait hostility on hostile feelings and aggressive thoughts. Aggressive Behavior 23(3), 161-178. 
Anderson, C. A., Berkowitz, L., Donnerstein, E., Huesmann, L. R., Johnson, J. D., Linz, D., \& Wartella, E. (2003). The influence of media violence on youth. Psychological Science in the Public Interest 4(3), 81-110.

Anderson, C., A., Shibuya, A., Ihori, N., Swing, E., L., Bushman, B., J., Sakamoto, A., \& Saleem, M. (2010). Violent video game effects on aggression, empathy, and prosocial behavior in eastern and western countries: a meta-analytic review. Psychological Bulletin, 136(2), 151-173.

Arnett, J. J. (2007). Adolescents' use of media for self-socialization. Journal of Youth and Adolescence 24(5), 519-533.

Benesty, J., Chen, J., Huang, Y., and Cohen, I. (2009). Noise reduction in speech processing (Vol. 2), Pearson correlation coefficient. (pp.37-40). New York: Springer-Verlag Berlin Heidelberg.

Berkowitz, L. (1965). Advances in experimental social psychology (Vol.2). The concept of aggressive drive: Some additional considerations (pp. 301 - 329). New York: Academic Press Inc.

Berkowitz, L. (1993). Aggression: Its causes, consequences, and control. New York: McGraw Hill.

Bettencourt, B., Talley, A., Benjamin, A. J., \& Valentine, J. (2006). Personality and aggressive behavior under provoking and neutral conditions: A meta-analytic review. Psychological Bulletin, 132(5), 751-777.

Bushman, B.J., \& Geen, R.G. (1990). Role of cognitive-emotional mediators and individual differences in the effects of media violence on aggression. Journal of Personality and Social Psychology, 58(1), 156-163.

Bushman, B. J., \& Huesmann, L. R. (2001). Effects of televised violence on aggression. In D.G. Singer \& J.L. Singer (Eds.), Handbook of children and the media (pp. 223- 254). Thousand Oaks, CA: Sage.

Bushman, B. J., \& Anderson, C. A. (2009). Comfortably numb: Desensitizing effects of violent media on helping others. Psychological Science, 20(3), 273-277.

Buss, A. H., \& Perry, M. (1992). The aggression questionnaire. Journal of Personality and Social Psychology, 63(3), 452-459.

Brains, H. K. (2015). Contemporary Media: Influence over Indian masses. IOSR Journal of Humanities and Social Science, 20(1), 103-107. doi:10.9790/0837-2012103107.

Browne, K. D., \& Hamilton-Giachritsis, C. (2005). The influence of violent media on children and adolescents: a public-health approach. The Lancet, 365(9460), 702-710.

Boulton, M. J., Bucci, E., \& Hawker, D. D. (1999). Swedish and English secondary school pupils' attitudes towards, and conceptions of, bullying: Concurrent links with bully/victim involvement. Scandinavian Journal of Psychology, 40(4), 277-284.

Chauhan, P., \& Reppucci, N. D. (2009). The impact of neighborhood disadvantage and exposure to violence on self-report of antisocial behaviour among girls in the juvenile justice system. Journal of Youth and Adolescence, 38(3), 401-416.

Chin, W. W. (1998). Commentary: Issues and opinion on structural equation modelling. MIS Quarterly, 22 (1), vii-xvi.

Coyne, S., M., Archer, J., \& Eslea, M. (2006). "We're not friends anymore! unless...": The frequency and harmfulness of indirect, relational, and social aggression. Aggressive Behavior, 32(4), 294-307. doi:10.1002/ab.20126. 
Desai, K. K., \& Basuroy, S. (2005). Interactive influence of genre familiarity, star power, and critics' reviews in the cultural goods industry: The case of motion pictures. Psychology \& Marketing, 22(3), 203-223.

Department of Statistics. (2010). Population distribution and basic demographic characteristics. Retrieved from http://www.statistic.gov.my/portal/download/Population/files/census 2010/TaburanPenduduk/dan_Ciri-ciri_Asas Demografi. Pdf. (2010, April 1). Date Accessed 2020, August 16.

Dodge, K. A. (1993). Social-cognitive mechanisms in the development of conduct disorder and depression. Annual Review of Psychology, 44(1), 559-584.

Duru, C. K., Redzuan, M. R., Hamsan, H., \& Shahrimin, M. I. (2015). Attitude to aggressive behaviour and intention of aggressive behavior among adolescent school children in Selangor stateMalaysia. Research on Humanities and Social Sciences, 5(3), 130-139.

Gagné, M., H., Drapeau, S., Melançon, C., Saint-jacques, M. C., \& Lépine, R. (2007). Links between parental psychological violence, other family disturbances, and children's adjustment. Family Process, 46(4), 523-542.

Ghazali, A. H. A., Samah, A. A., Omar, S. Z., Abdullah, H., Ahmad, A., Shaffril, H. A. M. (2020). Predictors of Cyberbullying among Malaysian Youth. Journal of Cognitive Sciences and Human Development. 6(1), 67-80.

Geen, R. G. (1976). Observing violence in the mass media: Implications of basic research. In R.G Geen \& E.C. O' Neal (Eds.), Perspectives on aggression, (pp. 193-234). New York: Academic Press.

Gentile, D. A., Coyne, S., \& Walsh, D. A. (2011). Media violence, physical aggression, and relational aggression in school age children: a short-term longitudinal study. Aggressive Behaviour, 37(2), 193-206.

Gentile, D. A. (2014). Media violence and children: A complete guide for parents and professionals. Santa Barbara, California: ABC-CLIO, LLC.

Goranson, R. E. (1970). Media violence and aggressive behavior: A review of experimental research. Advances in Experimental Social Psychology, 5, 1-31.

Govindam, K. (2001). Tamil Thraipadangalil Saathi, Matha Pethangal. Chennai: Kumaran Publishers.

Hassan, M. S., Osman, M. N., \& Azarian, Z. S. (2009). Effects of watching violence films on the altitudes concerning aggression among middle schoolboys (13-17 years old) at International Schools in Kuala Lumpur, Malaysia. European Journal of Scientific Research, 38(1), 141-156.

Haswell, M. (2011). Personal history of violence and response to violence: A quantitative and free response study focusing on college-age students. (Degree Thesis, Providence College, United states). Retrieved from http://digitalcommons.providence.edu/socialwrk_students/73.

Himmelweit, H. T., Oppenheim, A. N., \& Vince, P. (1958). Television and the child. London, UK: Nuffield Foundation.

Huesmann, L. R., \& Miller, L. S. (1994). Long-term effects of repeated exposure to media violence in childhood. In L. R. Huesmann (Ed.), Aggressive behaviour: Current perspectives (pp.153-186). New York: Plenum Press.

Jesudoss, P. (2009). Tamil cinema. Centre for the study of communication and culture, Vol. 28 (4). Retrievedfromhttp://www.biomedsearch.com/article/Tamilcinema/215411742.html.Data Accessed 2020, July 26. 
Keating, J., \& Matyas, T. (1998). Unreliable inferences from reliable measurements. The Australian Journal of Physiotherapy, 44(1), 5-10.

Krahe, B. (2012). Report of the media violence commission. Aggressive Behavior, 38(5), 335341.doi:10.1002/ab.21443.

Krishnan, H. (2012). Malaysian Indians and gangsterism. (2014, May 10). Retrieved from http://www.Freemalaysiatoday.com/category/opinion/2012/08/23/ Malaysian-Indians-and-gangsterism.

Linder, J. R., \& Werner, N. (2012). Relationally aggressive media exposure and children's normative believe: Does parental mediation matter? Family Relations, 61(3), 488-500. doi:10.1111/j.1741- 3729.2012. 00707. Date Accessed 2020 July 16.

Linz, D. G., Donnerstein, E., \& Penrod, S. (1988). Effects of long-term exposure to violent and sexually degrading depictions of women. Journal of Personality and Social Psychology, 55(5), 758-768.

Mohamed, Z. A. (2010). Gengster India ganas Zaman Khan. Utusan Malaysia. Retrieved from http://www.1.utusan.com.my/utusan/info.as?y=2010\&dt=0920\&pub=utusan_malaysia\& sec=Jenayah\&pg=je_03.htm\&arc=hive (In Malay). Date Accessed 2020, August 9.

Muhammad, M. (2019). Media violence contents and its effect on the audience. Forum Komunikasi, $14(2), 40-63$.

Moon, H., \& Lee, S. (2020). Moderating effects of socio-ecological factors on the relationship between adolescent exposure to media violence and attitudes towards school bullying. Journal of Advanced Nursing, 10 (87), 1-13.

Mrug, S., Madan, A., \& Windle, M. (2015). Emotional desensitization to violence contributes to adolescents' violent behavior. Journal of Abnormal Child Psychology, 44(1), 75-86.

Muhammud, A. (2012). Penghuni Raudhatus Sakinah: Kajian terhadap latar belakang dan faktor salahlaku (Doctoral dissertation, University of Malaya, Kuala Lumpur). Retrieved from http://studentsrepo.um.edu.my/5233/1/AZLINA_BINTI_MUHAMMUD.pdf (In Malay). Date Accessed 2020, June 14.

Natesan, V. (2013). Nayagan and the Indian gangsterism. Malaysia Today. (2014, September 9). Retrieved on http://www.malaysia-today.net/nayagan-and-the-indiangangsterism (In Malay). Date Accessed 2020, June 16.

Ostrov, J., M., Gentile, D., A., \& Crick, N., R. (2006). Media exposure, aggression and prosocial behavior during early childhood: A longitudinal study. Social Development, 15(4), 612-627.

Pendakur, M. (2003). Indian popular cinema: Industry, ideology, and consciousness. New York, NY: Hampton Press.

Potter, W. J. (2002). The 11 myths of media violence. Thousand Oaks, CA: Sage Publications. Rahim, M., H., A., Ping, L., M., Yin, J., S., K., \& Phil, E., T., L. (2015). The appeal of violent content in entertainment media to Malaysian audiences: An inquiry into the influence of meaningmaking. Malaysian Journal of Society and Space, 11(9), 86-98.

Ranganathan, M. (2010). The pan-Tamil rhetoric in regional media. In M. Ranganathan \& U.M. Rodrigues (Eds.), Indian media in a globalised world (pp. 83-104). Hyderabad, India: Sage Publication

Rankin, G., \& Stokes, M. (1998). Reliability of assessment tools in rehabilitation: an illustration of appropriate statistical analyses. Clinical Rehabilitation, 12(3), 187-199. 
Ravi, B. K. (2014). Metamorphosis of content in Indian cinema: A critical analysis. Educational Research International, 3(3), 65-79.

Richmond, J., \& Wilson, J. C. (2008). Are graphic media violence, aggression and moral disengagement related? Journal of Managerial Psychology, 15(2), 350-357. doi: $10.1080 / 13218710802199716$.

Rivadeneyra, R. (2006). Do you see what I see? Latino adolescents' perceptions of the images on television. Journal of Adolescent Research, 21(4), 393-414.

Rosenkoetter, L. I., Rosenkoetter, S. E., \& Acock, A., C. (2009). Television violence: an intervention to reduce its impact on children. Journal of Applied Developmental Psychology, 30(4), 381-397.

Rule, B. G., \& Ferguson, T. J. (1984). The relations among attribution, moral evaluation, anger, and aggression in children and adults. In Mummendey. A (Eds.), Social Psychology of Aggression (pp.143-155). New York, NY: Springer Berlin Heidelberg.

Rule, B. G., \& Ferguson, T. J. (1986). The effects of media violence on attitudes, emotions, and cognitions. Journal of Social Issues, 42(3), 29-50.

Samsudin, A. R. (2001). Media dan identiti budaya: Membangunkan industri kandungan tempatan yang berdaya tahan. Jurnal Komunikasi, 17, 67-80 (In Malay).

Samsudin, A., R. (2003). Media and cultural identity: Media challenges on Malaysian society in the $21^{\text {st }}$ century, in Samsudin A. Rahim Communication Issues, Kuala Lumpur: Ampang Press.

Savage, J. (2004). Does viewing violent media really cause criminal violence? A methodological review. Aggression and Violent Behaviour, 10(1), 99-128.

Shanthiah, R. (2015). Sejarah perkembangan parti Malayan Indian congress di tanah Melayu (PhD thesis, University of Malaya, Kuala Lumpur, Malaysia). Retrieved from http://studentsrepo.um.edu.my/5895/ (In Malay).

Siegel, S. (1956). Nonparametric Statistics for The Behavioral Sciences. New York, NY: McGraw-Hill. Subramanian, L. (2007). Cinema Sila Paarvaigal. Madras: Tamil Puthakalayam.

Uhlmann, E., \& Swanson, J. (2004). Exposure to violent video games increases automatic aggressiveness. Journal of Adolescence, 27(1), 41-52.

Velicer, W., F., Huckel, L., H., \& Hansen, C., E. (2003). A measurement model for measuring attitudes toward violence. Personality and Social Psychology Bulletin, 15(3), 349-364.

Velu, N. (2002). Kadar jenayah di kalangan remaja India meresahkan. Utusan Online. (2016, July 28). Retrieved on http://ww1.utusan.com.my/utusan/info.asp?y=2002\&dt=0715\&pub=Utusan_ Malaysia\&sec=Forum\&pg=fo_01.html (In Malay). Date Accessed 2020, June 8.

Yaacob, Z. (2010). Pengaruh keganasan dalam media terhadap tingkah laku agresif remaja (Doctoral dissertation, Universiti Teknologi Malaysia,Faculty of Education, Malaysia). Retrieved from eprintis.utm.my/.../2/ZalehaYaacob MFP2010ABS.pdf. (In Malay). Date Accessed 2020, July 19.

Yahaya, A., Lee, G., M., Ma'alip, H., \& Dunggi, R. (2014). Pengaruh media berunsur agresif dan kesannya terhadap tingkah laku pelajar sekolah menengah. Kertas telah dibentangkan di National Action Research Conference 2014, Melaka, Malaysia. Retrived from http://www.researchgate.net/publication/264972758_PENGARUH_MEDIA_AGRESIF_DAN_K ESA NNYA_TERHADAP_TINGKAH_LAKU_PELAJAR_SEKOLAH_MENENGAH (In Malay). Date Accessed 2020, June 17. 
Weaver, A. J., Wilson, B. J. (2009). The role of graphic and sanitized violence in the enjoyment of television dramas. Human Communication Research 35(3), 442-463.

Willock, J., Deary, I. J., Edwards-Jones, G., Gibson, G. J., McGregor, M. J., Sutherland, A....\& Grieve, R. (1999). The role of attitudes and objectives in farmer decision making: Business and environmentally oriented behaviour in Scotland. Journal of Agricultural Economics, 50(2), 286303.

Zafar, A., \& Chaudhary, U. G. (2018). Effects of violence shown in media on children: A study of parent's perspective. Journal of Early Childhood Care and Education, 2, 61-73.

Zillmann, D. (1979). Hostility and aggression ( $1^{\text {st }}$ ed.). Hillsdale, NJ, England: Lawrence Erlbaum Associates, Inc. 